\title{
Pituitary adenylate cyclase activating peptide (PACAP) immunoreactivity and mRNA expression in the duck gastrointestinal tract
}

Received: 20 November 2001 / Accepted: 11 March 2002 / Published online: 26 April 2002

(C) Springer-Verlag 2002

\begin{abstract}
The presence and distribution of pituitary adenylate cyclase activating peptide (PACAP) immunoreactivity were studied in the duck gastrointestinal tract using immunohistochemistry and radioimmunoassays. Expression and distribution of PACAP mRNA were also studied using reverse transcriptase polymerase chain reaction (RT-PCR) and hybridization techniques. In addition, a partial coding sequence (cds) of the duck growth hormone-releasing hormone (GRF)/PACAP gene was identified. The presence of both PACAP-38 and PACAP-27 was demonstrated, the former being the predominant form. PACAP immunoreactivity was found in neurons and fibers of the enteric nervous system (ENS), in endocrine cells and in the gut associated lymphoid tissue (GALT). Double immunostaining showed that PACAP is almost completely colocalized with vasoactive intestinal peptide (VIP) in the ENS. Moreover, PACAP was also found in nitric oxide synthase (NOS)-containing neurons and nerve fibers. Radioimmunoassay (RIA) performed on denervated gut showed that more than one-half of the duodenal PACAP is extrinsic in origin. RT-PCR, Northern blot analysis and in situ hybridization confirmed the immunohistochemical data. The findings of the present study suggest that, in birds, PACAP may have multiple roles in regulating gastrointestinal functions.
\end{abstract}

Keywords Radioimmunoassay - Gene cloning and sequencing - In situ hybridization - Vasoactive intestinal peptide $\cdot$ Leukocytes $\cdot$ Campbell khaki duck · Anas platyrhynchos

N. Mirabella (国) C C. Squillacioti · M. Colitti · G. Germano A. Pelagalli $\cdot$ G. Paino

Department of Biological Structures, Functions and Technology, University of Naples "Federico II", Via Veterinaria 1,

80137 Naples, Italy

e-mail: mirabell@unina.it

Tel.: +39-081-5644204, Fax: +39-081-5644230

M. Colitti

Department of Animal Production Sciences, University of Udine, Via delle Scienze, 208, 33100 Udine, Italy

\section{Introduction}

Pituitary adenylate cyclase activating peptide (PACAP) is a glucagon/vasoactive intestinal peptide (VIP)/secretin family peptide. It was originally isolated from the ovine hypothalamus and found to exist as two forms with 27amino-acid (PACAP-27) and 38-amino-acid (PACAP-38) residues (Miyata et al. 1989, 1990), both derived from a 176-amino-acid precursor (Kimura et al. 1990).

The PACAP cDNA has been cloned in several mammalian (Kimura et al. 1990; Ogi et al. 1990; Okazaki et al. 1995) and non-mammalian vertebrates (McRory et al. 1995; McRory and Sherwood 1997; Alexandre et al. 2000; Fradinger and Sherwood 2000). PACAP and growth hormone-releasing hormone (GRF) are encoded within the same gene in non-mammalian vertebrates including birds. In mammals these two peptides are encoded on separate genes.

The amino acid sequence of PACAP is highly conserved throughout phylogeny (Ogi et al. 1990; Chartrel et al. 1991; Yasuhara et al. 1992; Parker et al. 1993; Matsuda et al. 1997). PACAP is largely expressed in the central nervous system and in peripheral organs including several non-neuronal tissues and is considered to be a ubiquitous chemical messenger with a vast range of biological effects (for a review, see Vaudry et al. 2000).

Both PACAPs exert their biological activity by binding three different types of receptors (Harmar and Lutz 1994): PAC ${ }_{1}$ receptor, which binds PACAP with a much higher affinity than VIP; and $\mathrm{VPAC}_{1}$ and $\mathrm{VPAC}_{2}$ receptors, which bind PACAP and VIP with similar affinities (for a review, see Harmar et al. 1998).

In the gastrointestinal tract, PACAP immunoreactivity is widely distributed (Uddman et al. 1991; Sundler et al. 1992; Köves et al. 1993; Ny et al. 1995; Olsson and Holmgren 1994; Nagahama et al. 1998) and PACAP mRNA has been found to be expressed in the intestine of some mammalian and non-mammalian species (Arimura 1992; McRory et al. 1995; Hannibal et al. 1998; Fradinger and Sherwood 2000; Matsuda et al. 2000). Gastrointestinal PACAP has both an intrinsic and extrinsic origin 
(Portbury et al. 1995; Hannibal et al. 1998) and seems to be involved in the modulation of gastrointestinal motility, secretion and proliferation (McConalogue et al. 1995; Lindström et al. 1997; for a review, see Läuffer et al. 1999).

Only few data are available regarding the presence of PACAP in the avian gastrointestinal tract. PACAP immunoreactivity has been described in developing (Salvi et al. 2000) and adult chickens (Sundler et al. 1992) and in the pigeon (Mirabella et al. 2000). However, juvenile GRF/PACAP mRNA has been found unexpressed in the chicken intestine (McRory and Sherwood 1997). Further information regarding the distribution, origin and coexistence of PACAP immunoreactivity and the expression and distribution of PACAP mRNA in the gastrointestinal tract is essential for understanding the role played by PACAP in the avian gastrointestinal functions.

In the present study we have, therefore, investigated the presence and distribution of PACAP in the duck gastrointestinal tract by means of radioimmunoassay (RIA) and immunohistochemistry. Double immunohistochemical stainings were performed to examine the possible colocalization of PACAP with other neurotransmitters. Using surgical denervation, the origin of PACAP-immunoreactive nerve fibers was also investigated. In addition, expression and distribution of PACAP mRNA were evaluated using reverse transcriptase-polymerase chain reaction (RT-PCR) and in situ hybridization.

\section{Materials and methods}

Adult Campbell khaki ducks (Anas platyrhynchos) of both sexes were used. They were anesthetized by intramuscular injection of ketamine $(25 \mathrm{mg} / \mathrm{kg})$ and then sacrificed by exsanguination. Specimens from the esophagus, crop, proventriculus (glandular stomach), ventriculus (muscular stomach), duodenum, jejunum, ileum, cecum and rectum were collected.

\section{Sequencing and mRNA expression and distribution}

Total RNA was extracted from duck hypothalamus using Triazol reagent (cat. no. 15596, Life Technologies, Milan, Italy).

\section{Primer design}

Primer3 Input software was used to design the primers. The primer sequences were: 5'-GATGGGATCTTCAGCAAAGC-3' (PACAP for) and 5'-AATACGCTACTCGGCGTCCT-3' (PACAP rev). These primers amplified a fragment of 270 bp (bases 253-523) of the chicken GRF/PACAP cds.

\section{$R T-P C R$}

RT-PCR reactions were performed by a "one-step" RT-PCR using a SuperScript one-step RT-PCR-platinum Taq kit (cat. no. 10928-034, Life Technologies, Milan, Italy). For each reaction, $2 \mu \mathrm{g}$ total RNA extracted from duck hypothalamus was retro-transcripted and amplified using an MJ thermal cycler (PT-100; MJ Research Inc., Waltham, MA). RT-PCR cycle conditions were as follows: cDNA synthesis: $50^{\circ} \mathrm{C}, 30 \mathrm{~min}$; SuperScript II RT inactivation: $94^{\circ} \mathrm{C}$, $2 \mathrm{~min}$; cDNA amplification: $\left[94^{\circ} \mathrm{C}(30 \mathrm{~s}), 58.3^{\circ} \mathrm{C}(30 \mathrm{~s}), 72^{\circ} \mathrm{C}\right.$ (1 min) 40 cycles]; $72^{\circ} \mathrm{C}(5 \mathrm{~min}), 15^{\circ} \mathrm{C}$.
The band of 270 bp cDNA was cut off from the gel and purified using Gel extraction kit (cat. no. GM420050 Genomed, Berlin-Mahlsdorf, Germany). It was then cloned using a dual promoter TOPO TA cloning kit containing pCRII-TOPO cloning vector (cat. no. 45-0640 Invitrogen, Groningen, The Netherlands) and sequenced (Primm, Milan). The same conditions were used to amplify PACAP cds in the duck gastrointestinal tract.

PCR reaction on RNA samples and using the same set of primers gave no amplification product, thus ruling out that the observed bands may be due to the presence of contaminant genomic DNA.

\section{In situ hybridization (ISH) histochemistry}

An oligodeoxyribonucleotide probe complementary to the nucleotides (138-182) in the partial cds of the duck PACAP gene (Genebank accession no. 12962932) was designed. The probe was a 45-mer (5'-TTTCCGGTAGCGGCTGTAGCTGTCCGTGAAGATGCCGTCTATGTG-3'), which encodes the first 15 amino acids of the duck PACAP 38. The probe was $3^{\prime}$-end labeled using a terminal transferase kit (cat. no. NEP100; NEN, Boston, MA) and $\left[{ }^{35} \mathrm{~S}\right]-d A T P$ (cat. no. NEG734H, specific activity $1,250 \mathrm{Ci} / \mathrm{mmol}$, $\mathrm{NEN})$. Free $\left[{ }^{35} \mathrm{~S}\right]$-nucleotides were separated from the radioactive probes by using Microspin G-25 columns (cat. no. 27-5325-01, Amersham Pharmacia Biotech., UK).

Fresh tissues were removed rapidly and frozen immediately by immersion in liquid nitrogen for subsequent cryosectioning $(10 \mu \mathrm{m})$. Sections were mounted on microscope slides and stored at $-70^{\circ} \mathrm{C}$ until used. Frozen, slide-mounted sections were thawed at room temperature and fixed subsequently for $30 \mathrm{~min}$ in $4 \%$ paraformaldehyde in $0.1 \mathrm{M}$ PBS, $\mathrm{pH} 7.4$, at $4^{\circ} \mathrm{C}$. Sections were then rinsed twice for $10 \mathrm{~min}$ each in $\mathrm{PBS}$ at $4^{\circ} \mathrm{C}$, dehydrated in increasing concentrations of ethanol and air dried. Probes were diluted to $5,000 \mathrm{cpm} / \mu \mathrm{l}$ in hybridization buffer [50\% formamide, $4 \times$ SSC (sodium saline citrate), $5 \times$ Denhardt's solution, $1 \%$ SDS (sodium dodecyl sulfate), $10 \%$ dextran sulfate, $0.1 \mathrm{M}$ dithiothreitol, $20 \mathrm{mM} \mathrm{NaHPO}$, $\mathrm{pH} 7.4,25 \mu \mathrm{g} / \mathrm{ml}$ poly(A), $25 \mu \mathrm{g} / \mathrm{ml}$ poly(C) and $250 \mu \mathrm{g} / \mathrm{ml}$ tRNA]. Hybridization was performed overnight at $42^{\circ} \mathrm{C}$ in a humidified chamber. Sections were washed in $1 \times \mathrm{SSC}$ at $55^{\circ} \mathrm{C}$, dipped in water and dehydrated. The dried hybridization sections were exposed to autoradiographic film (Biomax-MR; Kodak, Belgium) for 15 days at room temperature. Sections were then dipped in photographic emulsion (LM-1; Amersham), developed in Kodak D19 after 30 days and subsequently counterstained with hematoxylin.

The specificity of the hybridization signals was confirmed in the following control experiments: (1) some sections were hybridized with radioactive-labeled probes in competition with a 100 -fold molar excess of the same unlabeled probes. (2) Some sections were incubated with the labeled sense probe instead of the antisense oligodeoxynucleotide. (3) Some sections were pretreated with $0.005 \%$ ribonuclease A (Sigma) in RNAse buffer $[0.5 \mathrm{M} \mathrm{NaCl}, 10 \mathrm{mM}$ TRIS- $\mathrm{HCl}, \mathrm{pH} 8,1 \mathrm{mM}$ ethylenediaminetetraacetic acid (EDTA)] for $1 \mathrm{~h}$ at $37^{\circ} \mathrm{C}$.

\section{Immunohistochemistry}

Single and double fluorescent stainings were performed on frozen sections using antisera against PACAP-27 (rabbit, IHC 8922), PACAP-38 (rabbit, IHC 8920), substance P (guinea pig, GHC 7451), calcitonin gene related protein (CGRP) (guinea pig, GHC 6009) and VIP (guinea pig, GHC 7161), all purchased from Peninsula Laboratories Inc., and against NOS (rabbit, AB 5380), purchased from Chemicon International Inc. The procedures, including antibody specificity and cross-reactivity tests, have been previously described (Mirabella et al. 2001).

In addition, paraffin-embedded sections were used. Briefly, the specimens were fixed by immersion in Bouin's fixative $(12 \mathrm{~h})$ and after washing were processed for paraffin embedding in vacuo. The sections were treated by the peroxidase antiperoxidase (PAP) method (Sternberger 1979). Single PACAP-38 staining was performed using the same rabbit polyclonal primary antibody as in frozen sections. 


\section{Surgical denervation}

The ducks were anesthetized by an intramuscular injection of ketamine, $25 \mathrm{mg} / \mathrm{kg}$, intubated with an orotracheal tube, and a mixture of oxygen $(1 \mathrm{l} / \mathrm{min})$ and $2-3 \%$ isoflurane was administered. After the peritoneal cavity was incised, the duodenum, jejunum and rectum were alternatively exposed and denervated. Denervation was performed by cutting the attachment of the mesenterium at the mesenteric border of the gut, thus severing the connections between the vagal duodenal branches or duodenopancreatic plexus and the duodenum or between Remak's nerve and the jejunum or rectum. The ducks were allowed to survive for $48 \mathrm{~h}$, at which time they were sacrificed. After the collection, some of the specimens were processed according to single labeling immunohistochemical procedures for the detection of PACAP immunoreactivity.

\section{Tissue extraction and radioimmunoassays}

The assays were performed on normal $(n=5)$ and denervated $(n=5$ for each investigated tract) ducks according to previously described procedures (Mirabella et al. 2001).

\section{Results}

Immunohistochemistry

\section{General PACAP distribution}

PACAP immunoreactivity was primarily found in neurons and fibers of the ENS (Table 1). PACAP-positive nerve fibers were generally found distributed in all the layers of the examined gastrointestinal tracts. The density of the fibers varied between the layers and between the tracts. PACAP-positive neurons were also found. They were more numerous in the submucous than in the myenteric ganglia. In addition, PACAP immunoreactivity was found in endocrine and in leukocyte-like cells.

\section{Esophagus and crop}

PACAP-positive fibers were found to be numerous in the inner circular muscle and in the muscularis mucosae (Fig. 1a). They were poor in the outer longitudinal muscle. Positive fibers were also found to encircle the ade- nomeres of mucous glands (Fig. 1b, c). PACAP-positive neurons were found in both myenteric (Fig. 1d) and submucous (Fig. 1e) ganglia.

\section{Proventriculus}

PACAP-positive fibers were found to innervate the inner circular (Fig. 1f) and, to a lesser extent, the outer longitudinal muscle. The muscularis mucosae, which is composed of inner, outer and interglandular strands of smooth muscle tissue, was also innervated (Fig. 1f-h). Positive fibers were found around the alveoli and underneath the ductal epithelium of the deep proventricular glands and within the proventricular plicae (Fig. 1g-i). In addition, they frequently innervated blood vessels (Fig. 1f). PACAP-positive neurons were found in myenteric (Fig. 1j) and submucous ganglia and in ganglia located in the tunica mucosa (Fig. 1f). Some positive endocrine cells were observed in the deep proventricular glands (Fig. 1i).

\section{Ventriculus}

Fine, varicose PACAP-positive fibers, which ran parallel to the muscle bundles, were primarily found in the ventriculus muscle (Fig. 1m).

\section{Small intestine}

The density of PACAP-positive fibers was higher in the circular than longitudinal muscle (Fig. 2a, b). In the mucosal layer, positive, varicose fibers were located around the crypts and extended up in the villi (Fig. 2a-c). PACAP-positive cell bodies were found both in submucous (Fig. 2c) and myenteric ganglia. In these ganglia, PACAP-positive varicose fibers were observed to encircle both positive and negative cells. Rarely in the duodenum, the muscularis mucosae was very thin or absent so that positive neurons were observed to be located in close contact with the gland crypts. PACAP-positive endocrine cells were found both in the crypts (Fig. 2a) and villi.

Table 1 Distribution of PACAP immunoreactivity in the enteric nervous system of the duck ( $f$. fibers, $n$. neurons, l.m. longitudinal muscle, c.m. circular muscle, m.p. myenteric plexus, s.p. submu-

cous plexus, m.m. muscularis mucosae, m. mucosa, + low density, ++ medium density, +++ high density)

\begin{tabular}{|c|c|c|c|c|c|c|c|c|c|c|c|c|}
\hline & \multicolumn{2}{|c|}{ Esophagus and crop } & \multicolumn{2}{|c|}{ Proventriculus } & \multicolumn{2}{|c|}{ Ventriculus } & \multicolumn{2}{|c|}{ Small intestine } & \multicolumn{2}{|c|}{ Ceca } & \multicolumn{2}{|c|}{ Rectum } \\
\hline & f. & n. & f. & $\mathrm{n}$. & f. & n. & f. & n. & f. & n. & f. & n. \\
\hline 1.m. & + & & + & & + & & + & & + & & + & \\
\hline c.m. & +++ & & ++ & & ++ & & +++ & & ++ & & +++ & \\
\hline m.p. & + & + & + & + & + & + & + & + & ++ & + & +++ & + \\
\hline s.p. & + & + & + & + & & & ++ & ++ & ++ & + & ++ & ++ \\
\hline m.m. & ++ & & +++ & & & & & & & & & \\
\hline $\mathrm{m}$ & ++ & & +++ & ++ & & & +++ & & ++ & & +++ & + \\
\hline
\end{tabular}



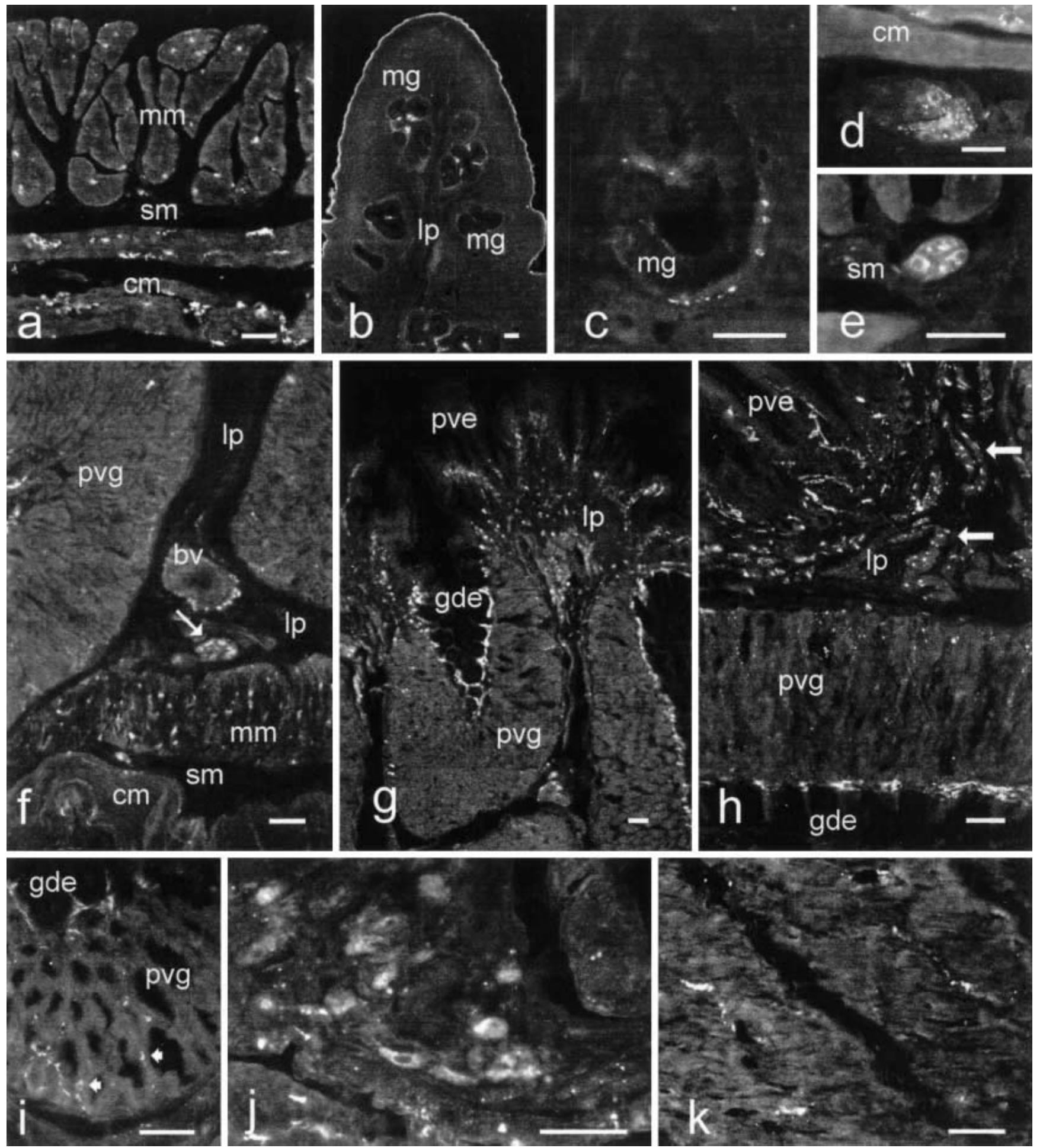

Fig. 1a-k Distribution of PACAP immunoreactivity (lp lamina propria, $\mathrm{mm}$ muscularis mucosae, $\mathrm{sm}$ tela submucosa, $\mathrm{cm}$ circular muscle, $m g$ mucous glands, $p v e$ proventricular epithelium, $p v g$ deep proventricular glands, gde epithelium of deep proventricular gland ducts, $b v$ blood vessel, small arrow a PACAP-positive ganglion located in the proventricular lamina propria, large arrows PACAP-positive nerve fibers in the inner strands of the proventricular muscularis mucosae, arrowheads endocrine cells in the deep proventricular glands). a, b, d, e Esophagus; c crop; f-j proventriculus; $\mathbf{k}$ ventriculus. In the esophagus and crop, PACAP- positive fibers innervated the circular muscular layer and the muscularis mucosae (a) and the mucous glands (b, c). PACAP-positive cell bodies and fibers were found in myenteric (d) and submucous (e) ganglia. In the proventriculus, PACAP-positive fibers innervated the circular muscular layer (f), the outer (f) and inner $(\mathbf{g}, \mathbf{h})$ strands of the muscularis mucosae, and the deep proventricular glands $(\mathbf{g}, \mathbf{h}, \mathbf{i})$. PACAP-positive cell bodies were found in mucous (f) and myenteric (j) ganglia. In the ventriculus PACAP-positive fibers primarily innervated the ventriculus muscle (k). Scale bar $50 \mu \mathrm{m}$ 


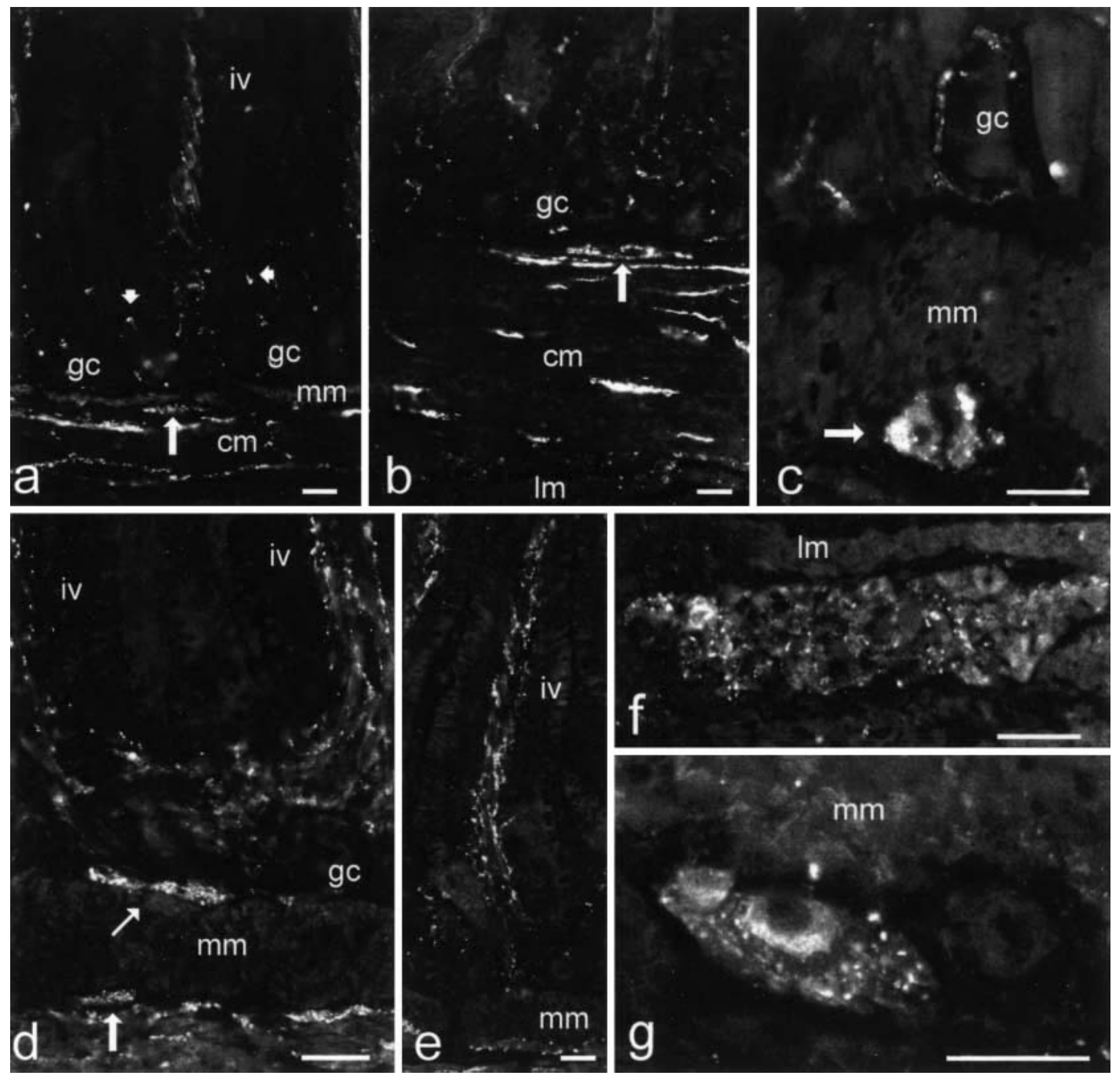

Fig. 2a-g Distribution of PACAP immunoreactivity in the small and large intestine ( $\mathrm{mm}$ muscularis mucosae, $\mathrm{cm}$ circular muscle, Im longitudinal muscle, $g c$ crypts, $i v$ villi, small arrow a PACAPpositive ganglion located in the lamina propria, large arrows submucous ganglia, arrowheads endocrine cells). a, b Duodenum; c jejunum; d-g rectum. In the intestine PACAP-positive nerve fibers were distributed in the mucosa and in the circular muscle (a-c, d-e). PACAP-positive cell bodies were found in the submucous $(\mathbf{c}, \mathbf{g})$ and myenteric (f) ganglia. Scale bar $40 \mu \mathrm{m}$

\section{Large intestine}

In the rectum, the general patterns of distribution of PACAP immunoreactivity were similar to those described in the small intestine (Fig. $2 \mathrm{~d}-\mathrm{g}$ ). Occasionally,
PACAP immunoreactivity was found in small ganglia located in the tunica mucosa (Fig. 2d). In the ceca, the density of positive neurons and fibers appeared to be lower than in the other parts of the intestinal tract. No positive endocrine cells were observed in the large intestine.

In all the examined tracts, small, rounded PACAP-positive cells with a lymphocyte-like feature were observed. These cells were primarily found in the connective core of the villi (Fig. 3a) and among crypts (Fig. 3b, c). They were also found in lymphoid aggregates (Fig. 3d, e). These aggregates were numerous in the esophagus, where they were frequently associated with mucous glands (Fig. 3e, f). 



Fig. 3a-f PACAP immunoreactivity in lymphocyte-like cells and lymphoid aggregates ( $v c$ connective core of the villi, $v e$ epithelium of the villi, $g c$ crypts, $l a$ lymphoid aggregates, oe esophageal epithelium, $m g$ mucous glands, gd mucous gland duct, small arrows PACAP-positive fibers, large arrows PACAP-positive lymphocyte-like cells, double arrows submucous ganglia, arrowhead endocrine cell). a, d Duodenum; b rectum; c jejunum; e, f esophagus. PACAP-positive lymphocyte-like cells were found in the connective core of the villi (a) and among crypts (b). These cells were morphologically and topographically distinct from endocrine cells (c). They were also observed in gastrointestinal lymphoid aggregates (d, e) and around mucous gland ducts in the esophagus (e). In some cases (d), PACAP-positive fibers were found to innervate large lymphoid aggregates. Scale bar $10 \mu \mathrm{m}$

\section{Colocalization studies}

PACAP and VIP were extensively colocalized in neurons and nerve fibers throughout the entire gastrointestinal tract (Fig. 4a-f). On the contrary, they were never colocalized in endocrine cells (Fig. 4g, h). PACAP and NOS

were frequently colocalized in submucous neurons (Fig. 4i, j). In all the tracts, CGRP or substance P, generally, was not expressed in PACAP-positive nerve fibers (Fig. 4k, 1).

\section{Denervation}

After the denervation, marked reduction of PACAP-positive nerve fibers was observed in the duodenum. These reductions were particularly seen in the mucosa, in the submucosal plexus and in the inner circular muscle (Fig. 5a, b). Jejunum and rectum (Fig. 5c, d) seemed to be unaffected.

\section{Radioimmunoassays}

The results are summarized in Fig. 6. In all the examined regions of the normal gastroenteric tract, the concentra- 




Fig. 4 PACAP/VIP (a-g), PACAP/NOS (i, j) and PACAP/CGRP $(\mathbf{k}, \mathbf{l})$ colocalization studies. Proventriculus (a, b), duodenum (c-h), rectum (i-l). PACAP (pacap) and VIP (vip) are colocalized $(\mathbf{a}-\mathbf{f})$ in neurons $(\mathbf{e}, \mathbf{f})$ and nerve fibers but not in endocrine cells $(\mathbf{g}, \mathbf{h})$. PACAP and NOS (nos) are frequently colocalized in submucous ganglia $(\mathbf{i}, \mathbf{j})$. PACAP and CGRP (cgrp) generally are not colocalized (k, l) (pve proventricular epithelium, pvg deep proventricular glands, $g c$ crypts, $i v$ villi, large arrows submucous ganglion cells, small arrows PACAP-positive leukocyte-like cells, double arrows PACAP-positive/CGRP-negative fibers, arrowhead a PACAP-positive/VIP-negative endocrine cell). Scale bar $50 \mu \mathrm{m}$ 
Fig. 5 PACAP immunoreactivity in control (a, c) and denervated ducks $(\mathbf{b}, \mathbf{d})$. PACAPimmunoreactive nerve fibers are clearly reduced after denervation in the duodenum $(\mathbf{a}, \mathbf{b})$ but not in the rectum $(\mathbf{c}, \mathbf{d})$ ( $\mathrm{gc}$ crypts, $\mathrm{mm}$ muscularis mucosae, smp submucous plexus, $\mathrm{cm}$ circular muscle). Scale bar $25 \mu \mathrm{m}$


tions of PACAP-38 were much greater than those of PACAP-27. The greatest concentrations of both forms were found in the duodenum, the lowest in the ventriculus. In the denervated duodenum, the concentration of PACAP-38 decreased from $5.28 \mathrm{pmol} / \mathrm{g}$ to $2.39 \mathrm{pmol} / \mathrm{g}$. No significant changes occurred after the denervation of the jejunum and the rectum.
PACAP sequencing and mRNA expression and distribution

The cDNA which was amplified and sequenced (AF343119) from the duck hypothalamus was highly homologous to that in the chicken (U67275). In particular, the PACAP partial cds in the duck is highly homologous (98\%) between 3967 and 4149 nucleotides of the exon 5 that encodes for a part of the chicken GRF and the entire PACAP (88-270 nt in the duck) and between 




a



b

Fig. 6 Concentrations of PACAP in normal (a) and denervated (b) ducks, $n=5$; values are given as means \pm SEM

3508 and 3596 nucleotides (92\%) of the exon 4 that encode for the chicken cryptic peptide and GRF (1-88 nt in the duck).

\section{RT-PCR and Northern blot analysis (data not shown)}

RT-PCR reaction and Northern blot analysis revealed the expression of PACAP mRNA in the hypothalamus as well as the gastrointestinal canal.

\section{ISH histochemistry}

ISH histochemistry revealed PACAP mRNA in myenteric and, to a lesser extent, submucous ganglion cells (Fig. $7 \mathrm{a}-\mathrm{c}$ ). In the proventriculus, PACAP mRNA was also found in mucosal ganglia (Fig. 7d). In the deep proventricular glands and jejunal villi, several ISH-positive cells were observed within the epithelium (Fig. 7d, e). In addition, in the mucosa-associated lymphoid aggregates numerous and intensely labeled positive cells were found. This was particularly evident in the esophagus, where these cells seemed to migrate towards the ducts of mucous glands (Fig. 7f). Intensely labeled positive cells were also found in lymphatic vessels (Fig. $7 \mathrm{~g}$ ), in the connective tissue of the core of the intestinal villi (Fig. 7h) and among crypts (Fig. 7i).

\section{Discussion}

The results of the present study demonstrate that both PACAP molecular forms are present in the duck gastrointestinal tract and that, as has been reported in several mammalian and non-mammalian tissues (Arimura et al. 1991; Hannibal et al. 1998; Montero et al. 1998; Mikkelsen et al. 1995; Fahrenkrug and Hannibal 1996; Mirabella et al. 2001), PACAP-38 is the dominant form.

Compared to mammals, some differences seem to occur regarding PACAP concentrations. Generally, PACAP-38 is less strongly expressed in the duck than in the rat intestine (Hannibal et al. 1998). In both these species, it is more strongly expressed in the small than in the large intestine. In the duck, PACAP-38 is more strongly expressed in the duodenum than in other tracts of the small intestine, and vice versa in the rat (Hannibal et al. 1998). Except in the mouse (Sundler et al. 1992), PACAP-27 is more strongly expressed in the duodenum and large intestine of the duck than in those of several mammalian species (Sundler et al. 1992; Hannibal et al. 1998).

RIA and immunohistochemistry performed in normal and denervated ducks have shown that PACAP has a dual intrinsic/extrinsic origin in the duodenum. It seems to be exclusively intrinsic in other tracts of the small and in the large intestine. This is consistent with the pattern of innervation of the avian gut.

Duodenum, indeed, receives innervation directly from vagus nerves through duodenal branches. In addition it is innervated by the duodenopancreatic plexus which, in turn, receives important contributions from vagal nerves as well as celiac and mesenteric ganglia. It may be speculated that part of the extrinsic PACAP to the duck duodenum represents both vagal afferent and efferent fibers. This hypothesis is supported by the presence of a strong PACAP immunoreactivity in the chicken vagus nerve. Moreover, PACAP-immunoreactive and/or PACAP mRNA-positive cells have been demonstrated in the vagal ganglia and vagal motor nuclei of both mammalian and avian species (Legradi et al. 1994; Mulder et al 1995; Peeters et al. 2000; Salvi et al. 2000).

The possibility that extrinsic duodenal PACAP-positive fibers also originate from celiac and mesenteric ganglia, however, cannot be excluded. Extrinsic PACAP has also been demonstrated in the guinea pig ileum (Portbury et al. 1995) and rat stomach (Hannibal et al. 1998).

The remnant part of the avian gut, from the distal duodenum to the end of the rectum, receives autonomic innervation from the intestinal Remak's nerve. This nerve is ganglionated and contains both sympathetic and parasympathetic fibers. Vagal and sacral parasympathetic fibers reach Remak's nerve through the celiac and mesenteric plexus and the pudendus (pelvic) nerve respectively (Bennett 1974; Baumel 1975). 


Despite the possibility that vagal PACAP-positive fibers reach the jejunum and rectum via Remak's nerve, extrinsic PACAP was not observed in these tracts of the intestine. It can be hypothesized that vagal PACAP-positive fibers interrupt their course and serve as preganglionic efferents in the ganglia of Remak's nerve. There is evidence that vagal fibers synapse on cell bodies in these ganglia (Pera 1962, 1963a, 1963b). Moreover, we observed in these ganglia (data not shown) numerous varicose PACAP-positive fibers encircling negative cells.

Immunohistochemical data showed that PACAP is widely distributed throughout the duck gastrointestinal tract. PACAP immunoreactivity was observed in both myenteric and submucous ganglia of all the investigated tracts and in endocrine cells. In addition, PACAP-positive fibers were observed in the muscular and mucosal layers, around and within the glands and corresponding with the muscular and submucosal blood vessels. These data agree, for the most part, with those reported from the chicken (Sundler et al. 1992), rat (Hannibal et al. 1998) and teleost fishes (Olsson and Holmgren 1994). They differ, however, from those reported from the guinea pig (Portbury et al. 1995) and from several other mammalian species, such as the cat, pig and mouse (Sundler et al 1992), in which PACAP seems to be absent from several tracts of the gastrointestinal mucosa.

The morphological findings provided by the present study suggest that PACAP plays a role in several nervemediated functions of the bird gastrointestinal tract. This is supported by the fact that $\mathrm{PAC}_{1}$ receptor mRNA is expressed in the avian gut (Peeters et al. 1999). Moreover, many functional studies indicate that PACAP has a potent relaxant activity on gastrointestinal smooth muscle (Katsolius et al. 1993; McConalogue et al. 1995; Yoshida et al. 2000) and important secretomotor properties throughout the gastrointestinal tract (Cox 1992; Kuwahara et al. 1993; Fuchs et al. 1996; Ozawa et al. 1997; Takeuchi et al. 1997).

The presence of positive cell bodies in ganglia located in the lamina propria of the proventricular mucosa suggests, in addition, a role for PACAP in the regulation of local mechanisms which control the activity of the muscularis mucosae and deep proventricular glands. It should be remembered that PACAP has evident stimulatory effects on gastric acid secretion. Indeed, it elicits histamine release from enterochromaffin cells (Lindström et al.

4 Fig. 7a-i Distribution of PACAP mRNA by ISH histochemistry ( $g c$ crypts, $\mathrm{mm}$ muscularis mucosae, $l p$ lamina propria, $p v g$ deep proventricular glands, $i v$ villi, $g d$ duct of an esophageal mucous gland, la lymphoid aggregate, $l v$ lymphatic vessel, large arrow ISH positivity in a proventricular mucosal ganglion). Esophagus $(\mathbf{a}, \mathbf{b}, \mathbf{f}, \mathbf{g})$, proventriculus $(\mathbf{d})$, duodenum $(\mathbf{h})$, jejunum (c, e) and rectum (i). ISH positivities were found in myenteric $(\mathbf{a}, \mathbf{b})$, submucous (c) and proventricular mucosal (d) ganglia. Intraepithelial ISH positivities (arrowheads) were found in the proventricular glands (d) and in the jejunal villi (e). In addition, intensely labeled positive cells (small arrows) were observed in lymphoid aggregates (f), in lymphatic vessels (g), in the connective tissue of the core of the villi (h) and among crypts (i). Scale bar $10 \mu \mathrm{m}$
1997; Lindström and Håkanson 2001) by binding PAC1 receptors and also activating L-type calcium channels (Zeng et al. 1999a, 1999b).

Colocalization studies disclosed that PACAP and VIP were almost completely coexpressed in the duck ENS. This almost complete PACAP/VIP colocalization represents a common finding in the avian peripheral nervous system (Sundler et al. 1992; Mirabella et al. 2000, 2001; Salvi et al. 2000). Many PACAP/VIP-positive neurons also expressed NOS, so that two classes of PACAP-positive intrinsic neurons, i.e., PACAP/VIP and PACAP/ VIP/NOS, seem to exist in the duck gastrointestinal tract. This confirms previous findings in the pigeon (Mirabella et al. 2000) and agrees with those reported in many non-avian species (Sundler et al. 1992; Olsson and Holmgren 1994; Portbury et al. 1995; Hannibal et al. 1998). PACAP, interacting with NO and VIP, in this case also via common receptors, may play an important role in mediating inhibitory non-adrenergic, non-cholinergic (NANC) neurotransmission in the avian gastrointestinal tract.

In the present study, the nucleotide sequence of GRF/PACAP partial cds of the duck was obtained by using RT-PCR (Genebank accession number AF343119). Comparison of the nucleotide and the deduced aminoacidic sequences with those of the chicken and mammals confirmed that this cDNA corresponds to PACAP. The identities with the complete cds of Gallus gallus GRF/PACAP were $98 \%$ and the amino acid positivities with GRF/PACAP polypeptide were the same. The high degree of nucleotide identity confirmed that this gene is highly conserved among species.

In contrast to that reported by McRory and Sherwood (1997), who did not detect GRF/PACAP mRNA from the juvenile chicken small and large intestine, PACAP mRNA expression was demonstrated in the duck gastrointestinal tract.

ISH results confirmed the immunohistochemical data. PACAP mRNA was found in both myenteric and submucous ganglia. However, a discrepancy was noted between ISH and immunohistochemistry regarding the density of PACAP-expressing cell bodies in submucous ganglia. Indeed, PACAP-immunoreactive cells were more numerous than ISH-positive cells and this could be due to differences in sensitivity between the two methods (Hannibal et al. 1998).

Immunohistochemistry and ISH demonstrated the presence of PACAP-producing cells in the gut-associated lymphoid tissue (GALT). The presence of PACAP-positive lymphocytes was immunohistochemically detected within the epithelium and the connective core of the duodenal villi in the rat (Gaytan et al. 1994). In addition, PACAP receptors are expressed in rat peritoneal macrophages (Pozo et al. 1997), thus suggesting an involvement for PACAP in the control of immune functions. PACAP, indeed, is reported to have a role in the regulation of the inflammatory process by stimulating histamine (Mori et al. 1994) and serotonin (Seebeck et al. 1998) secretion in mast cells, by modulating the produc- 
tion of cytokines in immune cells (Delgado et al. 1999a, 1999b; Martinez et al. 1996) and by inhibiting NO production from activated macrophages (Delgado 1999c). It can be hypothesized that in the duck gastrointestinal tract PACAP produced by GALT lymphocytes modulates the cytotoxic activity of macrophages in loco.

In conclusion, the results of the present study showed that PACAP is expressed in neuronal and non-neuronal tissues of the duck gastrointestinal tract and plays multiple roles in the regulation of avian gastrointestinal functions.

Acknowledgements The authors thank Mr. A. Calamo and Ms. S. Alì for their careful technical assistance.

\section{References}

Alexandre D, Anouar Y, Jégou S, Vaudry H (2000) Structure and distribution of the mRNAs encoding pituitary adenylate cyclase-activating polypeptide and growth hormone-releasing hormone-like peptide in the frog Rana ridibunda. J Comp Neurol 421:234-246

Arimura A (1992) Pituitary adenylate cyclase activating polypeptide (PACAP): discovery and current status of research. Regul Pept 37:287-303

Arimura A, Somogyvari-Vigh A, Miyata A, Mizuno K, Coy DH, Kitada C (1991) Tissue distribution of PACAP as determined by RIA: highly abundant in the rat brain and testes. Endocrinology 129:2787-2789

Baumel JJ (1975) Aves nervous system. In: Getty R (ed) The anatomy of the domestic animals, vol II. WB Saunders, Philadelphia, pp 2019-2062

Bennett T (1974) Peripheral and autonomic nervous system. In: Farner DS, King JR (eds) Avian biology, vol IV. Academic, London, pp 1-77

Chartrel N, Tonon MC, Vaudry H, Conlon JM (1991) Primary structure and biological activity of pituitary adenylate cyclase activating polypeptide (PACAP) from frog brain. Endocrinology 129:3367-3371

Cox HM (1992) Pituitary adenylate cyclase activating polypeptides, PACAP-27 and PACAP-38: stimulators of electrogenic ion secretion in the rat small intestine. $\mathrm{Br} \mathrm{J}$ Pharmacol 106:449-455

Delgado M, Munoz-Elias EJ, Gomariz RP, Ganea D (1999a) Vasoactive intestinal peptide and pituitary adenylate cyclase-activating polypeptide enhance IL-10 production by murine macrophages: in vitro and in vivo studies. J Immunol 162:17071716

Delgado M, Munoz-Elias EJ, Gomariz RP, Ganea D (1999b) VIP and PACAP inhibit IL-12 production in LPS-stimulated macrophages. Subsequent effect on IFNgamma synthesis by $\mathrm{T}$ cells. J Neuroimmunol 96:167-181

Delgado M, Munoz-Elias EJ, Gomariz RP, Ganea D (1999c) Vasoactive intestinal peptide and pituitary adenylate cyclase-activating polypeptide prevent inducible nitric oxide synthase transcription in macrophages by inhibiting NF-kappa B and IFN regulatory factor 1 activation. J Immunol 162:46854696

Fahrenkrug J, Hannibal J (1996) PACAP in the rat female genital tract: effect of capsaicin. Neuroscience 73:1049-1060

Fradinger EA, Sherwood NM (2000) Characterization of the gene encoding both growth hormone-releasing hormone (GRF) and pituitary adenylate cyclase-activating polypeptide (PACAP) in the zebrafish. Mol Cell Endocrinol 165:211-219

Fuchs M, Adermann K, Raab HR, Forssmann WG, Kuhn M (1996) Pituitary adenylate cyclase activating polypeptide: a potent activator of human intestinal ion transport. Ann N Y Acad Sci 806:640-647
Gaytan F, Martinez-Fuenetes AJ, Gracia-Navarro F, Vaudry H, Aguilar E (1994) Pituitary adenylate cyclase-activating peptide (PACAP) immunolocalization in lymphoid tissues of the rat. Cell Tissue Res 276:223-227

Hannibal J, Mikkelsen JD, Clausen H, Holst JJ, Wulff BS, Fahrenkrug J (1995) Gene expression of pituitary adenylate cyclase activating polypeptide (PACAP) in the rat hypothalamus. Regul Pept 55:111-115

Hannibal J, Ekblad E, Mulder H, Sundler F, Fahrenkrug J (1998) Pituitary adenylate cyclase activating polypeptide (PACAP) in the gastrointestinal tract of the rat: distribution and effects of capsaicin or denervation. Cell Tissue Res 291:65-79

Harmar T, Lutz E (1994) Multiple receptors for PACAP and VIP. Trends Pharmacol Sci 15:97-99

Harmar AJ, Arimura A, Gozes I, Journot L, Laburthe M, Pisegna JR, Rawlings SR, Robberecht, Said SI, Sreedharan SP, Wank SA, Waschek JA (1998) International Union of Pharmacology. XVIII. Nomenclature of receptors for vasoactive intestinal peptide and pituitary adenylate cyclase-activating polypeptide. Pharmacol Rev 50:265-270

Katsolius S, Clemens A, Schworer H, Creuzfeldt W, Schmidt WE (1993) Pituitary adenylate cyclase activating polypeptide (PACAP) is a potent relaxant of the rat ileum. Peptides 14:587-592

Kimura C, Ohkubo S, Ogi K, Itoh Y, Onda H, Miyata A, Jiang LDR, Stibbs HH, Arimura A, Fujino M (1990) A novel peptide which stimulates adenylate cyclase: molecular cloning and characterization of the ovine and human cDNAs. Biochem Biophys Res Commun 166:81-89

Köves K, Arimura A, Sándor V, Somogyvari Vigh A, Miller J (1993) Immunohistochemical localization of PACAP in the ovine digestive system. Peptides 14:449-455

Kuwahara A, Kuwahara Y, Mochizuki T, Yanaihara N (1993) Action of pituitary adenylate cyclase-activating polypeptide on ion transport in guinea pig distal colon. Am J Physiol 264:G433-G441

Läuffer JM, Modlin IM, Tang LH (1999) Biological relevance of pituitary adenylate cyclase activating polypeptide (PACAP) in the gastrointestinal tract. Regul Pept 84:1-12

Legradi G, Shioda S, Arimura A (1994) Pituitary adenylate cyclase activating polypeptide-like immunoreactivity in autonomic regulatory areas of the rat medulla oblongata. Neurosci Lett 176:193-196

Lindström E, Håkanson R (2001) Neurohormonal regulation of secretion from isolated rat stomach ECL cells: a critical reappraisal. Regul Pept 97:169-180

Lindström E, Bjorkqvist M, Boketoft A, Chen D, Zhao CM, Kimura K, Håkanson R (1997) Neurohormonal regulation of histamine and pancreastatin secretion from isolated rat stomach ECL cells. Regul Pept 71:73-86

Martinez C, Delgado M, Gomariz RP, Ganea D (1996) Vasoactive intestinal peptide and pituitary adenylate cyclase-activating polypeptide-38 inhibit IL-10 production in murine T lymphocytes. J Immunol 156:4128-4136

Matsuda K, Takei Y, Katoh J-I, Shioda S, Arimura A, Uchiyama M (1997) Isolation and structural characterization of pituitary adenylate cyclase activating polypeptide (PACAP)-like peptide from the brain of a teleost, starzager, Uranoscopus japonicus. Peptides 18:723-727

Matsuda K, Kashimoto K, Higuchi T, Yoshida T, Uchiyama M, Shioda S, Arimura A, Okamura T (2000) Presence of pituitary adenylate cyclase-activating polypeptide (PACAP) and its relaxant activity in the rectum of a teleost, the starzager, Uranoscopus japonicus. Peptides 21:821-827

McConalogue K, Furness JB, Vremec MA, Holst JJ, Tornoe K, Marley PD (1995) Histochemical, pharmacological, biochemical and chromatographic evidence that pituitary adenylyl cyclase activating peptide is involved in inhibitory neurotransmission in the taenia of the guinea-pig caecum. J Auton Nerv Syst 50:311-322

McRory JE, Sherwood NM (1997) Two protocordate genes encode pituitary adenylate cyclase-activating polypeptide and related family members. Endocrinology 138:2380-2390 
McRory JE, Parker DB, Ngamvongchon S, Sherwood NM (1995) Sequence and expression of cDNA for pituitary adenylate cyclase-activating polypeptide (PACAP) and growth hormonereleasing hormone $(\mathrm{GHRH})$-like peptide in catfish. Mol Cell Endocrinol 108:169-177

Mikkelsen JD, Hannibal J, Fahrenkrug J, Larsen PJ, Olcese J, McArdle C (1995) Pituitary adenylate cyclase activating peptide-38 (PACAP-38), PACAP-27, and PACAP related peptide (PRP) in the rat median eminence and pituitary. J Neuroendocrinol 7:147-155

Mirabella N, Lamanna C, Assisi L, Botte V, Cecio A (2000) The relationships of nicotinamide adenine dinucleotide phosphated to nitric oxide synthase, vasoactive intestinal polypeptide, galanin and pituitary adenylate activating polypeptide in pigeon gut neurons. Neurosci Lett 293:147-151

Mirabella N, Squillacioti C, Germano G, Varricchio E, Paino G (2001) Pituitary adenylate cyclase-activating peptide (PACAP) immunoreactivity in the ureter of the duck. Cell Tissue Res 305:341-349

Miyata A, Arimura A, Dahl R, Minamino N, Uehara A, Jiang L, Culler MD, Coy DH (1989) Isolation of 38 residue-hypothalamic polypeptide which stimulates adenylate cyclase in pituitary cells. Biochem Biophys Res Commun 164:567-574

Miyata A, Jiang L, Dahl R, Kitada C, Kubo K, Fujino M, Minamino $\mathrm{N}$, Arimura A (1990) Isolation of a neuropeptide corresponding to the $\mathrm{N}$-terminal 27 residues of the pituitary adenylate cyclase activating polypeptide with 38 residues (PACAP 38). Biochem Biophys Res Commun 170:643-648

Montero M, Yon L, Rousseau K, Arimura A, Fournier A, Dufour S, Vaudry H (1998) Distribution, characterization, and growth hormone-releasing activity of pituitary adenylate cyclase-activating polypeptide in the European eel, Anguilla anguilla. Endocrinology 139:104300-104310

Mori T, Kawashima T, Beppu Y, Takagi K (1994) Histamine release induced by pituitary adenylate cyclase activating polypeptide from rat peritoneal mast cells. Arzneimittelforschung 44:1044-1046

Mulder H, Uddman R, Moller K, Elsås T, Ekblad E, Alumets J, Sundler F (1995) Pituitary adenylate cyclase activating polypeptide is expressed in autonomic neurons. Regul Pept 59:121-128

Nagahama M, Tsuzuki M, Mochizuki T, Iguchi K, Kuwahara A (1998) Light and electron microscopic studies of pituitary adenylate cyclase-activating peptide (PACAP)-immunoreactive neurons in the enteric nervous system of rat small and large intestine. Anat Embryol (Berl) 198:341-352

Ny L, Larsson B, Alm P, Ekstrom P, Fahrenkrug J, Hannibal J, Andersson KE (1995) Distribution and effects of pituitary adenylate cyclase activating peptide in the cat and human lower oesophageal sphincter. Br J Pharmacol 116:2873-2880

Ogi K, Kimura C, Onda H, Arimura A, Fujino M (1990) Molecular cloning and characterization of cDNA for the precursor of rat pituitary adenylate cyclase activating polypeptide (PACAP). Biochem Biophys Res Commun 173:1271-1279

Okazaki K, Itoh Y, Ogi K, Ohkubo S, Onda H (1995) Characterization of murine PACAP mRNA. Peptides 16:1295-1299

Olsson C, Holmgren S (1994) Distribution of PACAP (pituitary adenylate cyclase-activating polypeptide)-like and helospectinlike peptides in the teleost gut. Cell Tissue Res 277:539-547

Ozawa M, Aono M, Mizuta K, Moriga M, Okuma M (1997) Central administration of PACAP stimulates gastric secretion mediated through the vagal pathway in anesthetized rats. Digest Dis Sci 42:2552-2558

Parker DB, Coe IR, Dixon GH, Sherwood NM (1993) Two salmon neuropeptides encoded by one brain cDNA are structurally related to members of the glucagon superfamily. Eur J Biochem 215:439-448
Peeters K, Gerets HHJ, Princen K, Vandesande F (1999) Molecular cloning and expression of a chicken pituitary adenylate cyclaseactivating polypeptide receptor. Mol Brain Res 71:244255

Peeters K, Gerets HHJ, Arckens L, Vandesande F (2000) Distribution of pituitary adenylate cyclase-activating polypeptide and pituitary adenylate cyclase-activating polypeptide type I receptor mRNA in the chicken brain. J Comp Neurol 423:6682

Pera L (1962) Sui rapporti tra fibre vagali e gangli del nervo intestinale di Remak in Gallus domesticus. Atti Soc Ital Anat 22:82

Pera L (1963a) Sul decorso delle fibre vagali contenute nel nervo intestinale del pollo. Proc Verb Soc Tosc Sci Natur Mem Ser B 70:26-39

Pera L (1963b) Sulla presenza di sinapsi tra neuroni pregangliari vagali e gangli del nervo intestinale nel pollo. Proc Verb Soc Tosc Sci Natur Mem Ser B 70:40-52

Portbury AL, McConalogue K, Furness JB, Young HM (1995) Distribution of pituitary adenylyl cyclase activating peptide (PACAP) immunoreactivity in neurons of the guinea-pig digestive tract and their projections in the ileum and colon. Cell Tissue Res 279:385-392

Pozo D, Delgado M, Martinez C, Gomariz RP, Guerrero JM, Calvo JR (1997) Functional characterization and mRNA expression of pituitary adenylate cyclase-activating polypeptide (PACAP) type I receptors in rat peritoneal macrophages. Biochim Biophys Acta 12:250-262

Salvi EP, Vaccaro R, Renda TG (2000) Ontogeny of PACAP immunoreactivity in extrinsic and intrinsic innervation of chicken gut. Peptides 21:1703-1709

Seebeck J, Kruse MI, Schmidt-Choudhury A, Schmidtmayer J, Schmidt WE (1998) Pituitary adenylate cyclase-activating polypeptide induces multiple signaling pathways in rat peritoneal mast cells. Eur J Pharmacol 352:343-350

Sternberger LA (1979) Immunocitochemistry. Wiley, New York

Sundler F, Ekblad E, Absood A, Håkanson R, Köves K, Arimura A (1992) Pituitary adenylate cyclase activating polypeptide: a novel vasoactive intestinal peptide-like neuropeptide in the gut. Neuroscience 46:439-454

Takeuchi K, Takehara K, Kato S, Yagi K (1997) PACAPs stimulate duodenal bicarbonate secretion of PACAP receptors in the rat. Am J Physiol 272:G646-G653

Uddman R, Luts A, Absood A, Arimura A, Ekelund M, Desai H, Håkanson R, Hambreaus G, Sundler F (1991) PACAP, a VIP-like peptide, in neurons of the esophagus. Regul Pept $36: 415-422$

Vaudry D, Gonzales BJ, Basille M, Yon L, Fournier A, Vaudry H (2000) Pituitary adenylate cyclase-activating polypeptide and its receptors from structure to functions. Pharmacol Rev $52: 269-324$

Yasuhara T, Mizuno K, Somogyvari-Vigh A, Sitton J, Komaki G, Arimura A (1992) Isolation and primary structure of chicken PACAP. Regul Pept 37:326

Yoshida M, Aizawa H, Takahashi N, Shigyo M, Hara N (2000) Pituitary adenylate cyclase activating peptide mediates inhibitory nonadrenergic noncholinergic relaxation. Eur J Pharmacol 395:77-83

Zeng N, Athmann C, Kang T, Lyu RM, Walsh JH, Ohning GV, Sachs G, Pisegna JR (1999a) PACAP type I receptor activation regulates ECL cells and gastric acid secretion. J Clin Invest 104:1383-1391

Zeng N, Athmann C, Kang T, Walsh JH, Sachs G (1999b) Role of neuropeptide-sensitive L-type $\mathrm{Ca}(2+)$ channels in histamine release in gastric enterochromaffin-like cells. Am J Physiol 277:G1268-G1280 